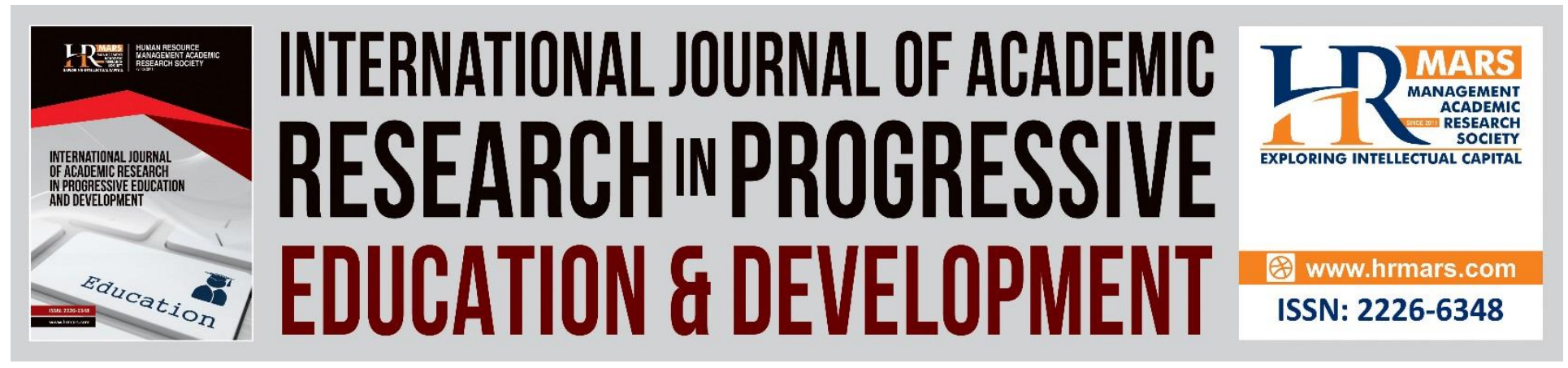

\title{
The Importance of Measurement and Evaluation Works in Academic Libraries
}

Wan Nor Haliza Wan Mokhtar, Norshila Shaifuddin, Halida Yu, Wan Satirah
Wan Mohd Saman, Norhayati Baba

To Link this Article: http://dx.doi.org/10.6007/IJARPED/v7-i3/4373

DOI: $10.6007 /$ IJARPED/v7-i3/4373

Received: 12 June 2018, Revised: 28 June 2018, Accepted: 03 July 2018

Published Online: 20 July 2018

In-Text Citation: (Mokhtar, Shaifuddin, Yu, Saman, \& Baba, 2018)

To Cite this Article: Mokhtar, W. N. H. W., Shaifuddin, N., Yu, H., Saman, W. S. W. M., \& Baba, N. (2018). The Importance of Measurement and Evaluation Works in Academic Libraries. International Journal of Academic Research in Progressive Education and Development, 7(3), 363-377.

Copyright: (C) 2018 The Author(s)

Published by Human Resource Management Academic Research Society (www.hrmars.com)

This article is published under the Creative Commons Attribution (CC BY 4.0) license. Anyone may reproduce, distribute, translate and create derivative works of this article (for both commercial and non-commercial purposes), subject to full attribution to the original publication and authors. The full terms of this license may be seen

at: http://creativecommons.org/licences/by/4.0/legalcode

\section{Vol. 7, No. 3, July 2018, Pg. 363 - 377}




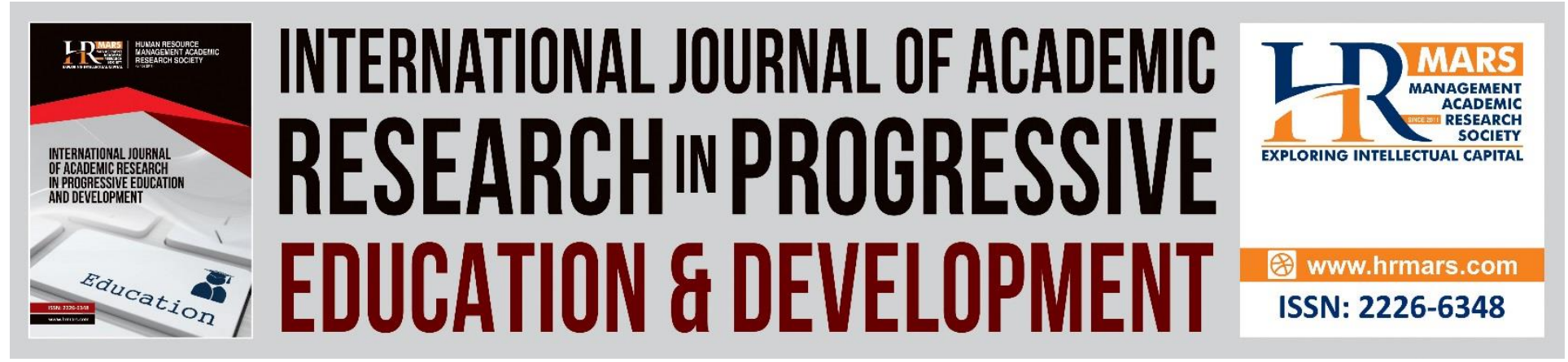

\title{
The Importance of Measurement and Evaluation Works in Academic Libraries
}

\author{
Wan Nor Haliza Wan Mokhtar, Norshila Shaifuddin, Halida Yu, \\ Wan Satirah Wan Mohd Saman, Norhayati Baba \\ Faculty of Information Management, Universiti Teknologi MARA, Malaysia \\ Email:whaliza@salam.uitm.edu.my,norshila74@salam.uitm.edu.my, \\ halid917@salam.uitm.edu.my, assatirah@salam.uitm.edu.my, norhayati2099@gmail.com
}

\begin{abstract}
This study focuses on the importance of measurement and evaluation practices of users' needs and expectations towards the facilities and services provided in the academic libraries. It provides the measurement and evaluation scenario of how the local academic libraries work on meeting and fulfilling the needs and expectations of their users. The study is generally significant in promoting and providing better facilities and services to the academic libraries users. This study employs qualitative approach to highlight the aim of the study in getting the actual position of measurement and evaluation practices in Malaysian academic libraries. This study adopted a case study approach to eight (8) academic libraries practicing the measurement and evaluation activities in their libraries. The results obtained from the survey conducted for the measurement and evaluation works have helped the libraries to construct the library strategic planning. This has drawn good impact on the library management system. The staff as well as the library users have benefited from the improvements done by the library.
\end{abstract}

Keywords: Measurement and evaluation, Performance Measurement, Library Service and Academic Library, Library Science

\section{Introduction}

A very established library is necessary to all academic institutions. It is very useful in supporting teaching, learning as well as research activities in the university and is expected to offer standard information resources to its users (Anunobi and Okoye, 2008). Therefore, every higher education institution considers the library as a central position on the campus.

In Malaysia, there are approximately 20 public academic libraries and 44 private academic libraries (Ministry of Higher Education, January, 2017) available in the country. University library consists of broad and varied collections of library materials and services. Traditionally, universities consider library as the heart of their institution (Research Information Network, 2007). A library is the place of fundamental important to every student, researcher, academic 
Vol. 7, No. 3, July 2018, E-ISSN: 2226-6348 @ 2018 HRMARS

and non-academic staff of the campus.

Service orientation organizations have identified the user as the most critical voice in assessing the service quality. At the same time, it is essential to identify what is the meaning of service quality to the users. This is important in assessing the service quality to be carried out effectively in academic libraries (Adeniran, 2011). The Research Information Network (2007) states that there are still many researchers who are always visiting their university library. They have few reasons why they normally go to the library. It is stated that the reasons could either be browsing the books, finding articles from the journals, recommending the library to do the books purchasing if they were not in the library collections, to concentrate during their study session or being away from their workplace because the library could be considered as a quiet place and conducive for them to do their work. Therefore, service quality at the academic libraries must always be in the good state in ensuring users are satisfied with the services offered at the libraries they are visiting. This is where the importance of measurement and evaluation works in academic libraries should be focused.

In terms of their functions, Kiran and Diljit (2012) stress that libraries are not like business entities. The adaptation of traditional services to electronic services travels beyond application of advanced technology in services delivery system. Therefore, library and information centre performance measurement is a very crucial managerial activity (Ninh, Tanner, Johanson and Denison, 2010). As stated by Cronin (1982), this activity is defined as "the process of systematically assessing effectiveness against a predetermined norm, standard or expressed goal". According to Slizyte and Bakanauskiene (2007), performance measurement is the comparison of the actual levels of performance with pre-established target levels of performance. Bawden (1990) describes that it is important for librarians to regularly evaluate the library offerings to the users. This is to ensure that the services and products are clearly justified based on the measurement and evaluation results. Nicholson (2004) emphasizes that based on the library evaluation history, there were multidimensional metrics of measures have been created that show the relationship between the measurement practices. Therefore, library assessor could get a more valuable knowledge on the library system besides the library officers becoming more informed on what to improve or provide in the library services while doing the decision-making processes. Based on that, the results of the evaluation are then closely related to the library strategic planning.

The study focuses on the measurement and evaluation practices of users' needs and expectations towards the facilities and services provided in the academic libraries. It provides the measurement and evaluation scenario of how the local academic libraries work on meeting and fulfilling the needs and expectations of their users. The study is generally significant in promoting and providing better facilities and services to the academic libraries users. The results obtained from the survey conducted for the measurement and evaluation works have helped the libraries to construct the library strategic planning. This has drawn good impact on the library management system. The staff as well as the library users have benefited from the improvements done by the library.

The academic library management team really appreciates the survey results obtained from the measurement and evaluation works. The results obtained from the survey could lead to the improvements and enhancements of the libraries facilities and services provided to the users. The results gain from the measurement and evaluation practices would be the good proof 


\section{INTERNATIONAL JOURNAL OF ACADEMIC RESEARCH IN PROGRESSIVE EDUCATION AND}

DEVELOPMENT

Vol. 7, No. 3, July 2018, E-ISSN: 2226-6348 @ 2018 HRMARS

for the libraries to make any changes in terms of current services provided to the users. As what have been found from this study, almost all academic libraries revealed that they have difficulty in making changes to the services provided to the users because of the financial constrains they are facing in their libraries. The situations have sometimes limit the enthusiastic libraries to move forward in terms of the library facilities and services issues. Because of that reason, the results from the survey could be used as the support evidence for the libraries to apply for the additional financial allocation from the parent organizations. Some of the management team of the university administration may request for the proof and evidence before approving the additional allocation to their respective academic libraries.

Apart from that, all academic libraries which involved in this study agreed that the creation of the standard metrics or indicators is very much needed. The standard ways of measurement and evaluation activities are very crucial to be implemented in the local academic libraries. Standard metrics or indicators in measuring and evaluating the library facilities and services provided by the libraries could impact the more valid results obtained from the survey. All informants of this study have revealed that all this while, they were using their own ways in conducting the measurement and evaluation works at their libraries. The measurement and evaluation team of the academic libraries are looking forward to refer to the standard metrics or indicators that suit to the local conditions of their academic libraries.

\section{Literature Review}

Today academic libraries not only limiting themselves to provide services like printed materials in the sense of developing their collection, doing cataloguing and classification, circulation, reference services, selective dissemination of information, current awareness, so do other bibliographic services, but have extended to interdisciplinary concepts such as telecommunication technology, the computer software and hardware and many other services (Anunobi and Okoye, 2008). Academic libraries these days are providing access to digital and electronic collections besides other services in complementing the information search process at the academic libraries (Kiran and Diljit, 2012). The services include the digital reference services, online document delivery, interlibrary loan, online helpdesk, as well as information skills tutorials.

Jankowska and Marcum (2010) inform that there is a variety factors on the growing concern that threaten the sustainability of academic libraries consist of developing and preserving print and digital collections, supplying and supporting vast changing of technology and network infrastructure, giving free services, maintaining growing costs of library buildings, as well as lowering libraries' ecological footprint. The importance of good services and facilities of the academic libraries become a big issue discussed by many parties. Measurement and evaluation of library services need to be considered by all academic libraries. In the digital age, academic libraries have various useful and creative services by offering excellence learning spaces, providing virtual reference services, creating metadata, choosing resources and managing resource licenses, teaching information literacy, maintaining digital repositories and collecting and digitizing archival materials (Campbell, 2006).

It is no doubt that measurement and evaluation practices give vital contributions to the academic libraries. The importance of measurement and evaluation practices of library services is another issue related to the library strategic planning. This includes ensuring the mission and 
Vol. 7, No. 3, July 2018, E-ISSN: 2226-6348 @ 2018 HRMARS

aspirations of a university are also considered by the library. The practice of measurement and evaluation of the library facilities and services is essential to the library strategic planning as a whole. Rudžionienè and Dvorak (2014) highlight the importance of measurement and evaluation works in the libraries are for the improvement of strategic planning, accountability, knowledge production, marketing, community consolidation, enlightening and learning. Thus, this shows that measurement and evaluation practices are crucial towards the library strategic planning.

\section{Research Method}

This research employs the intepretivism research paradigm. Interpretivism is also known as interpretivist. It involves researchers to interpret elements of the study, thus, interpretivism integrates human interest into a study. Interpretive reseachers consider that access to reality (given or socially constructed) is only through social constructions such as language, consciousness, and shared meanings as well as instruments (Dudovskiy, 2016). Myers (2008) highlights that development of interpretivist philosophy is based on the critique of positivism in social sciences. As for this study, researcher use qualitative method for research approach. Qualitative research is all about exploring issues, understanding phenomena, and answering questions.

Based on the researcher's philosophical stance, the qualitative approach was adopted to highlight the aim of the study in getting the actual position of measurement and evaluation practices in Malaysian academic libraries. This study adopted a case study approach to eight (8) academic libraries practicing the measurement and evaluation activities in their libraries. The librarians in charge with the measurement and evaluation works were the informants of the study. This selection has been based on their involvement in the measurement and evaluation activities at their libraries. Further to the study method, qualitative approach allows data to be collected from the informants. The data collection method was based on the semi-structured interviews. The constructions of librarians experiences into thematic forms, includes of how measurement and evaluation activities were carried out, the collections of statements and their views and tasks were collected. The analysis was done by using the thematic analysis technique.

\section{Findings and Discussions}

Findings have found that all eight (8) academic libraries acknowledged that the measurement and evaluation activities towards library facilities and services are necessary to them. Chadwell (2011) highlights that for more than a decade, measurement and evaluation has been a focus key area for academic libraries and their respective institutions. He added that the stakeholders of all kinds request the higher education to be accountable and to implement assessment strategies in monitoring and improving performance related to students learning and accessibility, community engagement and service as well as the research productivity. This statement has proven that the measurement and evaluation of library facilities and information services are very important to the academic libraries. Nicholson (2004) informs that it is found that from the past evaluation studies, most of the inspiration for measurement comes before the evaluation work. Therefore, he said understanding the topic and perspective of measurement undoubtedly before evaluating is necessary in developing a holistic understanding of a library. It is undeniable that the measurement and evaluation activities in the library are a necessity that must be addressed seriously. It does not matter whether the library is a public library or academic 


\section{INTERNATIONAL JOURNAL OF ACADEMIC RESEARCH IN PROGRESSIVE EDUCATION AND}

DEVELOPMENT

Vol. 7, No. 3, July 2018, E-ISSN: 2226-6348 @ 2018 HRMARS

library, indeed specific measurement and evaluation activities are a vital need to implement. This is parallel with the objective of the study which is:

To evaluate the measurement and evaluation approach used by Malaysian academic libraries in measuring their users' satisfactions

The main thing that can derive from the objective and that can be clearly seen from the findings is the need for measurement and evaluation activities and the assessment of the facilities and services to be provided in their academic libraries. RUSA (2008) states that cost, benefit, and quality assessments of library services could give meaningful and practical feedback for the library services improvement, staff training as well as the continuing education. In determining the levels of service effectiveness, the costs, the benefits, and the quality data must be judged in light of specific library goals, objectives, missions and standards. A variety ways of measurement and evaluation style like quality or success analysis, obtrusive, unobtrusive or mixed observation methods, cost and benefit analysis give invaluable information on staff performance, skill, knowledge, accuracy, as well as overall program effectiveness. For that, the findings have revealed the approaches used in measuring and evaluating users' satisfactions towards the library facilities and services provided by the academic libraries. It can be seen from the measurement and evaluation policy, the purpose, approach, instrumentation / metrics, assessment frequency and benchmarking of information services conducted in the libraries. Figure 1.1 is the "Library Measurement and Evaluation Practices Framework" that shows the approach or practices used by the local academic libraries in measuring and assessing the academic libraries facilities and services provided to the users.

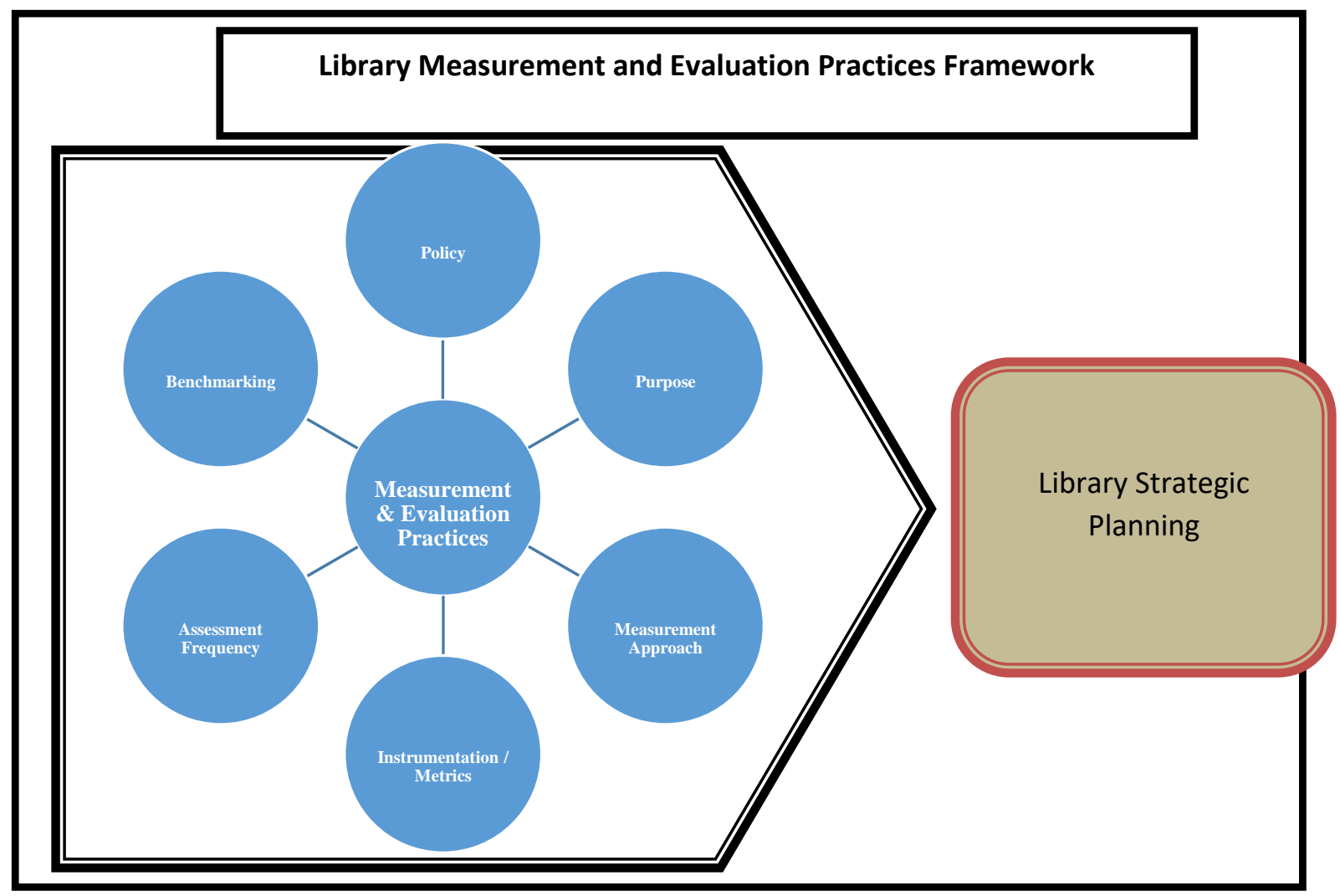

Figure 1.1: Library Measurement and Evaluation Practices Framework 


\section{Measurement and Evaluation Policy}

Some of the libraries have stated that the practice of measurement and evaluation are essential to their library as it is mentioned in the library policy. The policy states on the need for the practice of measurement and evaluation of facilities and services provided to the library users. The library policy states that the measurement and evaluation activity must be conducted continuously every year. Besides that, all libraries have informed that their libraries tend to do the measurement and evaluation activities during specific certain time as indicated in their library policy, and as to fulfill the International Organization of Standardization (ISO) requirements. All libraries agree that the International Organization of Standardization (ISO) implementation in their parent organizations as well as in the libraries is the reason why the libraries need to conduct the measurement and evaluation activities on regular basis as stated in their library policy.

\section{Measurement and Evaluation Purpose}

The purpose for measurement and evaluation practice is that the library can indirectly identify the needs or services required by their users. The respondents are given the opportunity to write comments and are able to express their needs in a transparent manner through the survey conducted by the library. All librarians interviewed, have acknowledged that the survey activity on library facilities and services to users must be continuously done so as to improve the services from time to time. Nicholson (2004) stresses that the conceptual framework for holistic evaluation can provide good metrics perspectives for library measurement and evaluation developed by previous research. Therefore, decision makers not only can better understand their system but also can answer to problems more promptly from the preexisting environment of evaluation. All are based on the feedback from the respondents.

From the findings, it can be concluded that the purpose of the measurement and evaluation practices are:

i. To measure how good is the library;

ii. To highlight the improvement factors on library services; and

iii. To enhance library expectation

Most informants from all libraries have agreed that measurement and evaluation practices are vital as to measure how good their libraries are. From the measurement and evaluation practice, users' perception could be gauged through the concept of quality and values.

According to Nicholson (2004), one of the ways to evaluate library services is by examining the concept of quality and values. Orr (1973) presents two basic questions to understand this separation: 'How good is the service?' and 'How much good does it do?'. Librarians need to take up different type of measurement from users in order to present this type of evaluation. Nicholson (2004) says librarians need to consider the users' viewpoint on their experiences instead of focusing only on the performance of the system. From this study, it is found that through the measurement and evaluation practices implemented in the library, the average stated that they have also seen an increased level of academic library services from year to year.

It is set that the result of the survey made available is as the improvement factors for the information, facilities, services and infrastructures offered to the library users as a whole. 
Vol. 7, No. 3, July 2018, E-ISSN: 2226-6348 @ 2018 HRMARS

Quality facilities, services improvements and supporting the staff that helped the users with good services can be formed to provide the best service to all users and aligned with the university goals to become a world-class university. The informant added that, with the comments, suggestions and complains received, the surveys conducted have also helped them in improving the library services provided to users as a whole.

Nicholson (2004) states that after the measurement work is implemented in the library, it must be followed by evaluation work. Measuring without evaluating is a common problem with automated reporting tools. He also added that, evaluation involves some method of judgment about the collected measures and metrics through some criteria. Judgment requires a viewpoint; different viewpoints may lead to different results. The university also considers the practice of measurement and evaluation of library services is also very important and must be given special attention. All libraries that are also the sample for this study have confirmed that they have never failed to conduct survey activities in their libraries since the activities were implemented in a consistent and persistent way. Distributions of questionnaires were made to obtain feedback from the library users.

Data obtained from the questionnaires distributed can help libraries to provide reports on the level of satisfaction of the library users. Reports on users' satisfaction are very important not only to the library, but also to the university administration. A long-term plan that involves financial strategies need to be addressed. With this report, guidance to libraries is provided as well as to the university administration to draw up short-term and long-term planning for an academic library's progress. Once the data analysis process is completed, most of the academic library report on the survey conducted would be prepared either at the end of the year or at the beginning of the year.

\section{Measurement and Evaluation Approach}

In order to make the measurement and evaluation activities run smoothly, each library would have to abide to certain rules and approach. Whatever the approach adopted by them, the goal of every library in implementing the measurement and evaluation activities is still the same - to measure the users' satisfactions towards the information resources, services and facilities provided by the library to the users. It is a comprehensive approach as users are given the opportunity to rate them on every aspect. The questionnaire covers everything about the library which is related to the users. Besides that, respondents are also given the opportunity to express their comments, views and suggestions in the questionnaire with regards to the facilities and services provided by the library. Every library provides space for the users to comment, to give their opinions and suggestions about the library they are using. This is indeed very important for the purpose of improvement and for the long-term planning of the library. As a result, the range of various evaluation criteria and the viewpoints is essential in gaining a more comprehensive understanding of the library itself (Nicholson, 2004).

Overall, it can be said that all academic libraries' respondents of this study employed the same approach in preparing the survey questions for the measurement and evaluation activities in their libraries.

\section{Measurement and Evaluation Instrumentation / Metrics}

From the survey, it was found that academic libraries use the questionnaire as an 


\section{INTERNATIONAL JOURNAL OF ACADEMIC RESEARCH IN PROGRESSIVE EDUCATION AND}

DEVELOPMENT

Vol. 7, No. 3, July 2018, E-ISSN: 2226-6348 @ 2018 HRMARS

instrument for data collection works in the measurement and evaluation of library facilities and services provided to the users by the library. The use of the library questionnaire helps the library to get feedback from users more easily and orderly. Each category on the criteria in the library survey is evaluated and organized by the committee. The analysis of the completed questionnaire can be done better and more effectively. Each point to be measured and evaluated related to the library information resources; information services, library services and facilities are also included in the questionnaire. It is thus, comprehensive to evaluate and measure the level of users' satisfactions with library services that comes from various group of users.

Rudžionienè and Dvorak (2014) inform that information specialists are facing the information management problems when seeking to fulfil users information needs constantly and continuously besides having to provide high-quality information services timely at the same time. The responses from the respondents are very important and useful to the library to measure and assess the level of users' satisfactions towards the facilities and services provided to them. The easiest method to get such information is through the use of questionnaires, distributed to the users. All eight (8) university libraries involved indicated that they have used the questionnaire as the instrument to collect data from the library users. However, the number of questions asked differs from one (1) library to another. All eight (8) libraries also admitted that since the last few years they have tried not to take too long time for users to answer the questions available in the questionnaire being distributed. Modifications to the questionnaire were made from time to time to make it more precise, shorter and simpler. Users can save time when answering. This is important as users are not interested to answer too many questions that demanded too much of their time.

Staffs working at the counter have played their role in distributing the questionnaire to the respondents. They are responsible to distribute and collect the completed questionnaire from the respondents. Dervin and Nilan (1986) mention that many scholars argue that the users' perspective is the most essential part in library evaluation. Library services are meant for the library users. Thus, the first evaluation aspect that should be taken into consideration is the users' evaluations. For each measure, the users' input, both formally (through library friends groups and focus groups), and informally (through conversations with the users) should be collected first. Therefore, the user can evaluate the facilities and services provided based on the evaluation criteria provided. Other participants in the process have not only gathered the data from the measurement and evaluation criteria but also from the users' viewpoint on that evaluation done (Nicholson, 2004).

Modifications on the questionnaires are carried out from time to time by the academic libraries involved in this study. The modified questionnaires that include new questions are basically done with a careful planning by the committee in charge. What emphasized are all issues related to information resources, services and facilities provided by the library. The new set of questionnaires are considered as comprehensive and could identify the level of users' satisfactions and meet the need for the library measurement and evaluation of library facilities and services as a whole. Normally, discussions on the questions that need to be included into the questionnaire are conducted among the committee. In the survey process, questionnaires from the previous year are always checked and examined as to whether it is still in line with the current situation. If its contents were no longer relevant, then the irrelevant questions are dropped from the list as to fit the current situation of one (1) particular year. 
Vol. 7, No. 3, July 2018, E-ISSN: 2226-6348 @ 2018 HRMARS

To avoid any inconveniences to the users, certain libraries have 'not asked the respondents for their identity in the demographic information part of the questionnaire. Here, identity includes the respondent's identification - their names, student or staff identity number. This is to avoid the uneasy feelings to the respondents when answering the questionnaire. They would not feel doubtful or scared when giving their views, comments and suggestions to the library. As a result, more relevant, valid and sincere feedbacks could be acquired from the respondents. This is very important for the betterment and improvement of the library. To sum up this issue, as suggested by Babalhavaeji, et. al. (2010), based on review on related literature, the academic libraries are reminded to use the International Organization of Standardization (ISO) standards to conducting their own evaluation studies; predominantly, in the design of the questionnaires or evaluation checklists which are suitable to their specific current environment they live in, to cope up with challenges and to try to offer quality information services.

McNicol (2005) states in her research that there is a number of cases in which the library director took personal responsibility for setting high-level priorities which were then discussed and developed by the management team. She further added that a small number of libraries have made use of external consultants or facilitators to help formulate a plan. While in some cases, the library's strategic plan was outlined by the senior management team and then circulated to staff for comments. In another instances, the management team has produced a draft plan based on an initial consultation process. At times, some specific areas of the plan were developed further by working groups consisting of staff with a direct interest in that area. In most institutions, the library's strategic planning was approved by a committee, such as the information committee, library committee and student association, but this was not generally the case.

Dahler-Larsen (2006) informs that there is a significant style of evaluation, different paradigm and conception of evaluation practiced by organizations. This could influence the confusion related to the evaluation concept since it is very dynamic and complex phenomenon.

Most of the libraries involved in this study took about $10 \%$ of the total number of library users as the respondents to fill in the questionnaires. Every academic library also has its own schedule to distribute the questionnaire to the respondents. The distribution of the questionnaires started at a regular interval. This is to make sure that they have enough time to distribute and collect the filled in questionnaires back from the respondents as a whole. Some academic libraries even take the initiative to give tokens to respondents who took part in completing the questionnaire for the measurement and evaluation activities in their library.

Rudžionienè and Dvorak (2014) mention that a rapidly growing information flows has given the challenge to the society globally these days. To expedite the work of measurement and evaluation of library facilities and services, all eight (8) libraries participated in this study need to assigned one (1) specific department to handle and manage the measurement and evaluation activities. The measurement and evaluation practice is then conducted comprehensively by this responsive team. In the AL1B Library for instance, the Customer Service Department is responsible in coordinating all activities related to the measurement and evaluation practices of the library. The Customer Services Department is responsible to do this work with the help from the survey committee.

The retrieval of the completed questionnaires differs from one (1) library to another. To get back $100 \%$ of questionnaires distributed from the respondents is almost impossible. 
Vol. 7, No. 3, July 2018, E-ISSN: 2226-6348 @ 2018 HRMARS

However, if the library has managed to collect back more than $50 \%$ of the questionnaires distributed, then it is considered as good. The return of completed questionnaires increase from time to time. With the increase collection of completed questionnaires, it has indirectly helped the library to get accurate and comprehensive feedbacks from the users as a whole. Basically, all plans made by the library for the benefits of the users can be implemented efficiently and more effectively. For other libraries, as a whole, they have managed to collect back more than half of the actual distributions of the questionnaires from the respondents. It is considered as sufficient and good enough as it represent most of the users' responses towards their satisfactions on the facilities and services provided by the library.

\section{Measurement and Evaluation Assessment Frequency}

To ensure measurement and evaluation practices are implemented properly, a resolution was made by each library concerned about the possible frequency of questionnaires distributions to users in its libraries. All the libraries did not choose the same period of time for the questionnaires distributions in their libraries. However, the distributions often follow the month and the period set out in their libraries policy. Table 1.1 shows the frequency of measurement and evaluation practices conducted in the libraries sampled out for this study:

Table 1.1

Frequency of Measurement and Evaluation Assessment

\begin{tabular}{|c|c|c|}
\hline & Library & $\begin{array}{c}\text { The Frequency of Measurement and Evaluation } \\
\text { Assessment }\end{array}$ \\
\hline 1. & AL1A & $\begin{array}{ll} & \text { Conducted twice a year } \\
\text { - } & \text { January - June and July - December } \\
\text { - } & \text { Analysis in July and January }\end{array}$ \\
\hline 2. & AL1B & $\begin{array}{ll}\text { - } & \text { Conducted once a year } \\
\text { - } & \text { October - December } \\
\text { - } & \text { Analysis in January }\end{array}$ \\
\hline 3. & AL1C & $\begin{array}{ll} & \text { Conducted once a year } \\
\text { - } & \text { September - November } \\
\text { - } & \text { Analysis in December }\end{array}$ \\
\hline 4. & AL1D & $\begin{array}{ll}\text { - } & \text { Conducted once a year } \\
\text { - } & \text { April - September } \\
\text { - } & \text { Analysis in November }\end{array}$ \\
\hline 5. & AL2A & $\begin{array}{ll}\text { - } & \text { Conducted once a year } \\
\text { - } & \text { January - April } \\
\text { - } & \text { Analysis in May }\end{array}$ \\
\hline 6. & AL2B & $\begin{array}{ll}\text { - } & \text { Conducted once a year } \\
\text { - } & \text { January - March } \\
\text { - } & \text { Analysis in April }\end{array}$ \\
\hline 7. & $\mathrm{AL2C}$ & - Conducted once a year \\
\hline 8. & AL2D & - $\quad$ Conducted four (4) times a year \\
\hline
\end{tabular}

The frequency of the measurement and evaluation works differs from one (1) library to 
Vol. 7, No. 3, July 2018, E-ISSN: 2226-6348 @ 2018 HRMARS

another. They have their own schedules as to when the survey works should be conducted. Basically, all the libraries carried out the survey every year.

It is undeniable that every measurement and evaluation activity of the libraries have their own reasons in conducting the survey. Academic libraries are no exception in this regard. The main purpose of the survey is to gain knowledge on the level of users' satisfaction of the services offered in their libraries. From the analysis of the data collected in the survey work, the academic libraries have also done improvements to the facilities and services provided at the libraries. On the other hand, all the academic libraries which were also the respondents of this study have agreed that they carry out the measurement and evaluation activities in their libraries due to the implementation of the International Organization of Standardization (ISO), and the quality standards implementations. Kate-Riin and Jantson (2013) highlight that the International Organization of Standardization (ISO) implementations in organizations are crucial for many reasons. Such implementations act as the strategic tools that reduce costs by minimizing waste and errors besides increasing productivity. To increase productivity in the academic libraries were very much needed since the libraries are dealing with the public to deliver services offered in the libraries. Measurement and evaluation practices need to be done to see the level of users' satisfactions towards services provided. It can be said that all academic libraries have done the measurement and evaluation of facilities and services provided by the libraries systematically ever since the enforcement of the implementation of the International Organization of Standardization (ISO) and quality standards in the local universities respectively.

All libraries were also involved in the evaluation of the International Organization of Standardization (ISO) and the quality standards in the whole universities as well as in the libraries. The evaluations cover the services offered in the library that contribute to knowledge, information resources, facilities and relevant information needed by the university communities; in particular, the university students, lecturers and researchers. Babalhavaeji et. al. (2010) stress that the aim of having the standard in the library is to prevent failures or mistakes, and not merely to only detect them after they have occurred. Praditteera (2001) mentions that it cannot solve its problems on its own but it helps to identify them. In defining the value of standardization for its work, the International Organization for standardization has introduced the International Organization of Standardization (ISO). Poll (2006) says the issues which are most relevant for library and information services consist of quality, safety, reliability, compatibility, efficiency and effectiveness (Babalhavaejiet. al., 2010).

\section{Measurement and Evaluation Benchmarking}

Benchmarking is one (1) of the most important elements in the measurement and evaluation practices. As mentioned by AL2C Library, survey practices has contributed significantly to the existence of the library standards in the preparation of a client charter and the standard operating procedure (SOP). According to the informant of AL2C Library, their client charter is important because it becomes the benchmark for quality facilities and services to the users.

Subsequently, all respondents in this study have acknowledged that the practice of measurement and evaluation of library facilities and services are necessary to their organizations. With the availability of measurement and evaluation practices, they found that all services offered to the users could be valued by their effectiveness. Sources of information, facilities, services and equipment provided at the library would all be measured and assessed as to whether 
Vol. 7, No. 3, July 2018, E-ISSN: 2226-6348 @ 2018 HRMARS

the library meets the needs of users as a whole or otherwise. As stated by Bawden (1990), librarians should evaluate their offerings on a regular basis to ensure to make informed decisions and justify services provided by the library. On the other hand, Agarwal (2011) indicate that as the academic libraries continue to grow and expand, there would be demands on the management of the organization which relate to the higher users' expectations, staff transparency as well as the constant pressure on profitability.

From the study, the respondents have acknowledged that the measurement and evaluation activities is the most effective way to 'communicate' with the users and relate with the library services offered to them. As stated by the informant of AL1C Library, measurement and evaluation activities are the best and most accurate method to be implemented by the libraries to measure and evaluate the effectiveness of facilities and services offered to their users. Surveys carried out are using formal methods in getting feedback from the libraries users related to the facilities and services provided to the library users. This method is considered as relevant and reliable which could be as reference to the management team of the libraries for various purposes. For example, for the International Organization of Standardization (ISO) works and office quality practices, the organizations need accurate data to make decisions and in creating the strategic planning for their libraries. If there is any deficiency in any case, they can also find initiatives for improvement of the library facilities and services to the users as a whole. Previously, survey conducted by the library to measure and evaluate users' satisfaction was normally just an exception, and not something that is compulsory (Saunders, 2007).

\section{Conclusion}

Measurement and evaluation works need to be implemented continuously. Proper planning on how to conduct the survey need to take into consideration by the measurement and evaluation team at every academic library. The survey conducted in the frequent interval could help the library to see the trend of users' needs and expectation from time to time. The related academic libraries could make proper plans on the library facilities and services improvements at their libraries. This is important to ensure that the academic libraries could provide the best library facilities and services in the academic libraries to fulfill the needs and expectation of the users. Improvement on the library facilities and services could be made from time to time based on the result obtained from the survey conducted by the academic libraries every year.

\section{References}

Adeniran, P. (2011). User satisfaction with academic libraries services: Academic staff and students perspectives. International Journal of Library and Information Science, 3(10), 209-216. Retrieved from http://doi.org/10.5897/IJLIS11.045

Agarwal, T. (2011). Measuring effort in service organisations. Retrieved on August 17， 2012, from

http://www.vantedge.in/uploads/4/5/2/7/4527963/measuring_effort_in_servic e_organi sations.pdf

Anunobi, C. V. \& Okoye, I. B. (2008). The role of academic libraries in universal access to print and electronic resources in the developing countries. Library Philosophy and Practice, 2008(2000), 1-5. 
INTERNATIONAL JOURNAL OF ACADEMIC RESEARCH IN PROGRESSIVE EDUCATION AND DEVELOPMENT

Vol. 7, No. 3, July 2018, E-ISSN: 2226-6348 @ 2018 HRMARS

Babalhavaeji, F., Isfandyari-Moghaddam, A., Aqili, S. V., \& Shakooii, A. (2010). Quality assessment of academic libraries' performance with a special reference to information technology-based services: suggesting an evaluation checklist. The Electronic Library, 28(4), pp. 592-621. Retrieved from http://doi.org/10.1108/02640471011065409

Bawden, D. (1990). User-Oriented Evaluation of Information Systems and Services, Aldershot: Gower.

Campbell, J.D. (2006). Changing a cultural icon: The academic library as a virtual destination. Educause Review 41 (1), 66 - 3.

Chadwell, F. A. (2011). Assessing the Value of Academic Library Consortia. Journal of Library Administration, 51(7/8), 645-661. Retrieved from http://doi.org/10.1080/01930826.2011.601268

Cronin, B. (1982). Taking the measure of service. ASLIB Proceedings, 34(6/7), pp.273- 94.

Dahler-Larsen, P. (2006). When Evaluation meets the "Rough Ground" in Communities. Evaluation, 12(4), 496-505.

Dervin, B., \& Nilan, M. (1986). Information needs and uses. Annual Review of Information Science and Technology. Retrieved from http://doi.org/10.1016/S00225371(63)80069-9

Dudovskiy, J. (2016). Research Methods. Research Methodology. N.p., 2016. Web. 10 May 2016.

Jankowska, M.A., \& Marcum, J.W. (2010). Sustainability challenge for academic libraries: planning for the future. College \& Research Libraries, 71, 160-170. Retrieved from http://doi.org/Article

Kate-Riin, K. \& Jantson, S. (2013). Library employees' attitudes towards the measurement and appraisal of their work performance: Study in Estonian University libraries. Library Management, 34(6/7), pp. 521 - 537

Kiran, K., \& Diljit, S. (2012). Modeling Web-based library service quality. Library and Information Science Research, 34(3), 184-196. Retrieved from http://doi.org/10.1016/j.lisr.2012.02.005

McNicol, S. (2005). The challenges of strategic planning in academic libraries. New Library World, 106(11/12), pp.496 - 509.

Ministry of Higher Education (2017). Retrieved on January 3, 2017, from https://www.mohe.gov.my/en/

Myers, M.D. (2008). Qualitative Research in Business \& Management. SAGE Publications.

Nicholson, S. (2004). A conceptual framework for the holistic measurement and cumulative evaluation of library services. In Proceedings of the ASIST Annual Meeting. 41, pp. 496-506). Retrieved from http://doi.org/10.1002/meet.1450410158

Ninh, K. T., Tanner, K., Johanson, G., \& Denison, T. (2010). Systematic performance measurement for university libraries in Vietnam. Library Management, 31(8/9), 702716. Retrieved from http://doi.org/10.1108/01435121011093469

Orr, R. H. (1973). Measuring the goodness of library services: A general framework for considering quantitative measures. Journal of Documentation, 29(3), 315-332. Retrieved from http://doi.org/10.1108/eb026561 
INTERNATIONAL JOURNAL OF ACADEMIC RESEARCH IN PROGRESSIVE EDUCATION AND DEVELOPMENT

Vol. 7, No. 3, July 2018, E-ISSN: 2226-6348 @ 2018 HRMARS

Poll, R. (2006). Standardized measures in the changing information environment. Performance Measurement and Metrics, 7(3), pp.127 - 141.

Praditteera, M. (2001). ISO 9000 implementation in Thai academic libraries. Pittsburgh: University of Pittsburgh.

Reference and Users Services Association of American Library Association (RUSA, 2008). Chicago: American Library Association. Retrieved January 2, 2017 from http://www.ala.org/rusa/

Research Information Network (2007). Researchers' use of academic libraries and their services. Retrieved on June 2, 2016 from http://www.rin.ac.uk/system/files/attachments/Researchers-libraries-servicesreport.pdf

Rudžionienè, J., \& Dvorak, J. (2014). Public administration approach What do libraries need for consistent information services evaluation. Library Management, 35(6/7), 495507. Retrieved from http://doi.org/10.1108/LM-02-2014-0019

Saunders, L. (2007). Regional Accreditation Organizations' Treatment of Information Literacy: Definitions, Collaboration, and Assessment. Journal of Academic Librarianship, 33(3), 317-326. Retrieved from http://doi.org/10.1016/j.acalib.2007.01.009

Slizyte, A. \& Bakanauskiene, I. (2007). Designing performance measurement system in organization. Organizacij Vadyba: Sisteminiai Tyrimai, 43, 135-148. 